\title{
Correlation between Body Mass Index and abdominal circumference in Belgian adults: a cross-sectional study
}

\author{
GAËLLE WILMET, ROLF VERLINDE, JAN VANDEVOORDE, LAURE CARNOL, DIRK DEVROEY
}

Department of Family Medicine and Chronic Care, Vrije Universiteit Brussel, Belgium

\begin{abstract}
Introduction. Traditionally, the body mass index (BMI) is used to describe anthropometric measurements and to assess weight-related health risks. However, the abdominal circumference (AC) might also be a valuable parameter to estimate this risk. This study aims to describe an association between the BMI and the AC.

Material and Methods. Participants were recruited during the Brussels Food Fair in 2014. They completed a questionnaire with their medical history, and health related parameters such as blood pressure, weight, height and $\mathrm{AC}$ were measured.

Results. In total, 705 participants were analyzed. Men had a mean BMI of $27.3 \mathrm{~kg} / \mathrm{m}^{2}$ and a mean AC of $98.7 \mathrm{~cm}$. Women had a mean BMI of $26.0 \mathrm{~kg} / \mathrm{m}^{2}$ and a mean AC of $88.2 \mathrm{~cm}$. The Pearson's correlation coefficient between the BMI and the AC was 0.91 for men and 0.88 for women. There was a strong positive correlation between the BMI and the AC. In the identification of patients at high risk for weight-related diseases, the use of the AC identified more patients than the BMI. Especially more women were ranking in a higher risk class with the AC than with the BMI classification. Both the $\mathrm{BMI}$ as well as the $\mathrm{AC}$ identified most diseases with an increased relative risk.

Conclusion. There is a strong correlation between the BMI and the AC. There are too few arguments to prefer the use of $\mathrm{AC}$ above the $\mathrm{BMI}$ to detect people at high risk for weight-related diseases.
\end{abstract}

Keywords: Body mass index, abdominal circumference, weight-related diseases.

\section{INTRODUCTION}

Overweightness and obesity are defined by the World Health Organization (WHO) as abnormal or excessive fat accumulation that may impair [1]. The body mass index (BMI) allows to assess the prevalence of overweightness and obesity within a population and to estimate the associated risk of developing comorbidities [2].

BMI is applicable in adults, but it is not a good predictor of adult obesity or adult disease in children and adolescents. However, BMI was found to be reasonably good for diagnosing obesity during childhood [3]. The BMI is a very popular measurement because it is simple. A BMI of $30 \mathrm{~kg} / \mathrm{m}^{2}$ or more was highly specific (97\%) but not sensitive (42\%) in order to detect obesity. For people with a BMI of $25 \mathrm{~kg} / \mathrm{m}^{2}$ or more, the index had a sensitivity of $86 \%$ and a specificity of $73 \%$ to detect overweightness [4].

With the BMI, no distinction is made between excess weight caused by excessive body fat, or muscle mass. As a result, the same BMI may not always correspond to the same fat percentage. The relationship between the two varies depending on the physique, the body proportions, and the age and gender of the subjects $[1,2,4]$.
The BMI gives only an idea about the amount of total fat - at best, but obese individuals differ in their fat distribution, which can be central, intraabdominal and visceral. The localization of the excess body fat is important, because it plays a role in the co-morbidities and the prognosis. For this reason it is necessary to use a different anthropometric measurement. The abdominal circumference (AC) or waist circumference can be easily measured and corresponds to the intra-abdominal fat, and is associated with the possibly related health problems. A change in the $\mathrm{AC}$ reflects a change in the risk factors for cardiovascular diseases and chronic conditions $[1,2,4]$.

Lean et al. suggested gender-specific cutoffs for AC, which are adopted by the World Health Organization (WHO), and are widely used $[1,5,6]$. The cutoffs are based on a heterogeneous sample of caucasian men and women.

There are some concerns when using the $\mathrm{AC}$ as a screening tool. Firstly, the AC can estimate a higher or lower risk for smaller or taller people with a similar AC. Secondly there are different thresholds for men and women $[6,7]$.

In addition, the limits are based on studies conducted with people of European origin. In their literature review, Lear et al. provided an overview of the limits for the different population groups [8]. 
It also became clear that the more pregnancies women have had, the greater their AC was, even after adjusting for age and BMI [9].

\section{Association of BMI and AC with co-morbidities and mortality}

Traditionally, the BMI is used to quantify weight disorders and to estimate health risks. Alternative measurements such as AC, waist-to-hip ratio (WHR) and waist-to-height ratio (WhtR) are also used. Several studies have shown that both $\mathrm{BMI}$ and AC accurately predict cardiovascular risk. In 2008, Huxley et al. concluded that AC is the best discriminator of prevalent diabetes and hypertension, and is more strongly associated with prevalent diabetes (but not hypertension), as compared to BMI [10]. Another meta-analysis concluded that the measurement of central obesity, especially WhtR, had a superior discriminatory ability for cardiovascular risk, as compared to BMI. But the differences were small and unlikely to be of clinical relevance. The authors did not recommend one of the four measurements more than the others [11].

Huxley et al. concluded that there is an association between the measurements for general obesity (BMI) and abdominal obesity (AC or WHR) with cardiovascular risk factors and events [12]. Only for diabetes, the measurements for abdominal obesity were better predictors than BMI. This was not the case for hypertension, dyslipidemia and cardiovascular mortality. Vazquez et al. showed that the relative risk to develop diabetes was similar for BMI, AC and WHR [13].

Qiao and Nyamdorjalso concluded that for the assessment of the individual risk of diabetes the measurement of the $\mathrm{AC}$ was not superior as compared to the other anthropometric measurements [14].

Seidell found that both AC and WHR are related to an increased risk for overall mortality [15]. WHR is an important predictor of severe obstructive sleep apnea.

Cerhan et al. concluded that an increased AC among caucasian adults is associated with an increased mortality from respiratory disease in men, and cardiovascular disease among women, while the relationship was weaker but still significant for $\mathrm{AC}$ and cancer for both men and women [16]. The relationship was linear in the different BMI categories. According to the authors, the AC should always be determined, even for individuals with normal BMI.

\section{Correlation between BMI and AC}

Vazquez et al. analyzed the correlation between several overweight indicators [13]. They found a strong correlation $(\mathrm{r}=0.88)$ between BMI and AC, but a much weaker one between BMI and WHR $(\mathrm{r}=0.34)$ and between AC and WHR $(\mathrm{r}=0.4)$.

Flegal et al. also calculated the correlation between anthropometric parameters for men and women [17]. Their results also showed a strong correlation between BMI and AC ( $\mathrm{r}=0.89$ for males and $r=0.87$ for women) but in contrast to Vazquez, the relationship between AC and WHR was robustly correlated $(\mathrm{r}=0.76$ for men and $\mathrm{r}=$ 0.70 for women). The correlation between BMI and WHR was moderate for men $(r=0.53)$ and women $(\mathrm{r}=0.39)$. Also Cerhan et al. found a robust correlation between $\mathrm{AC}$ and BMI for men $(\mathrm{r}=0.77)$ and women $(\mathrm{r}=0.72)$ [16].

This study aims to report on anthropometric data of men and women and to assess the correlation between BMI and AC. Secondly, the association of weight-related diseases and the BMI and $\mathrm{AC}$ will be assessed.

\section{MATERIAL AND METHODS}

\section{Study population}

All adult visitors of the 2014 Brussels Food Fair could participate in the research. Visitors who reported to be pregnant or had signs of alcohol, drugs, or medication abuse were excluded for participation. After they received information about the study and after they had signed the informed consent, the participants had to complete a paper questionnaire. The questionnaire enquired on demographics, education, medical history, actual diseases, actual treatment and diets ever followed. Subsequently, the following parameters were measured: weight, height, $\mathrm{AC}$, heart rate and blood pressure.

\section{Approval of the ethical committee}

The study protocol was approved by the ethical committee of the University Hospital Brussels.

\section{Measurements}

Weight was measured with a digital personal scale SecaSensa 804. The measurement of the height was done with a Seca 206 wall-mounted measuring tape. The AC was measured, standing on bare foot, and after normal exhalation, with a Seca 201 ergonomic circumference measuring tape, halfway between the top of the iliac crest and the lowest point of the lower rib. It was rounded to $0.1 \mathrm{~cm}$. Blood pressure was measured with a calibrated DS-54 WelchAllyn sphygmomanometer blood 
pressure device with an accuracy of $1 \mathrm{mmHg}$. The heart rate was determined by counting the number of heartbeats at the level of the radial artery.

\section{Data management and statistical analysis}

The body mass index was calculated for each participant by dividing his/her weight $(\mathrm{kg})$ by the square ofhis/her length $\left(\mathrm{m}^{2}\right)$. The BMI was allocated into three categories, ranging from normal weight $\left(\mathrm{BMI}<25 \mathrm{~kg} / \mathrm{m}^{2}\right)$, to overweight $\left(25 \mathrm{~kg} / \mathrm{m}^{2}<\mathrm{BMI}<\right.$ $\left.30 \mathrm{~kg} / \mathrm{m}^{2}\right)$ and obese $\left(B M I \geq 30 \mathrm{~kg} / \mathrm{m}^{2}\right)$. The AC was also allocated into three categories with genderspecific cutoffs: normal risk $(\leq 80 \mathrm{~cm}$ for women and $\leq 94 \mathrm{~cm}$ for men), increased risk (between 80 $88 \mathrm{~cm}$ for women and $94-102 \mathrm{~cm}$ for men) and high risk ( $\geq 88 \mathrm{~cm}$ for women and $\geq 102 \mathrm{~cm}$ for men).

The statistical analyses are primarily descriptive and were carried out with SPSS 22. Most of the results are presented separately for women and men. The significance of differences between discrete variables were examined by applying the Chi-square test. T-tests were performed for continuous variables. In order to study the correlation between the BMI and AC, the Pearson's and Spearman's rank correlation coefficients were calculated for both sexes.

\section{RESULTS}

\section{Demographics}

This observational cross-sectional study included 725 participants. Data from 705 individuals who met all criteria were analyzed, 458 women $(65 \%)$ and 247 men (35\%). Datasets of twenty participants were not processed due to the lack of necessary information, such as gender or the year of birth.

The mean age of women (54.6 years) and men (56.0 years) was not significantly different $(\mathrm{p}=$ 0.31 ). There were significantly more non-smokers among the women (79\%) as compared to men (67\%) (Table 1).

Men had a mean BMI of $27.3 \mathrm{~kg} / \mathrm{m}^{2}$ and a mean $\mathrm{AC}$ of $98.7 \mathrm{~cm}$. Both these values were significantly lower in women: $26.0 \mathrm{~kg} / \mathrm{m}^{2}$ and $88.2 \mathrm{~cm}$, respectively $(\mathrm{p}<0.001)$. In addition, the systolic and diastolic blood pressure was also higher in men (131 and $79 \mathrm{mmHg}$, resp) than in women (125 and $77 \mathrm{mmHg}$, resp) $(\mathrm{p}<0.001$ and $\mathrm{p}<0.05$, resp).

Table 1

Demographics of the study population

\begin{tabular}{|c|c|c|c|c|c|}
\hline \multirow[b]{2}{*}{ Anthropometric variables } & \multicolumn{2}{|c|}{$\begin{array}{c}\text { Men } \\
(\mathbf{N}=\mathbf{2 4 7})\end{array}$} & \multicolumn{2}{|c|}{$\begin{array}{c}\text { Women } \\
(\mathbf{N}=\mathbf{4 5 8})\end{array}$} & \multirow[b]{2}{*}{ p-value } \\
\hline & Value & SD & Value & SD & \\
\hline Age (years) & 56.0 & 17.9 & 54.6 & 17.6 & 0.31 \\
\hline Weight $(\mathrm{kg})$ & 83.1 & 14.2 & 67.8 & 12.4 & $<0,001$ \\
\hline Height $(\mathrm{cm})$ & 174.5 & 7.4 & 161.6 & 6.6 & $<0.001$ \\
\hline Body Mass Index $\left(\mathrm{kg} / \mathrm{m}^{2}\right)$ & 27.3 & 4.2 & 26.0 & 4.7 & $<0.001$ \\
\hline Abdominal circumference $(\mathrm{cm})$ & 98.7 & 12.4 & 88.2 & 12.0 & $<0.001$ \\
\hline Cardiovascular variables & Value & SD & Value & SD & p-value \\
\hline Systolic blood pressure (mmHg) & 131 & 16 & 125 & 16 & $<0.001$ \\
\hline Diastolic blood pressure $(\mathrm{mmHg})$ & 79 & 11 & 77 & 10 & $<0.05$ \\
\hline Heart rate (beats/min) & 72 & 12 & 74 & 11 & 0.06 \\
\hline Smoking status & $\mathbf{n}$ & $\%$ & n & $\%$ & p(2)-value \\
\hline Smoker & 28 & 11 & 42 & 9 & $<0.05$ \\
\hline Former smoker & 53 & 22 & 52 & 11 & \\
\hline Non-smoker & 166 & 67 & 363 & 79 & \\
\hline Marital status & $\mathbf{n}$ & $\%$ & $\mathbf{n}$ & $\%$ & p(4)-value \\
\hline Single & 49 & 20 & 105 & 23 & $<0.01$ \\
\hline Divorced & 6 & 2 & 50 & 11 & \\
\hline Living together & 36 & 15 & 53 & 12 & \\
\hline Married & 146 & 59 & 196 & 43 & \\
\hline Widow(er) & 10 & 4 & 53 & 11 & \\
\hline Education & $\mathbf{n}$ & $\%$ & $\mathbf{n}$ & $\%$ & p(4)-value \\
\hline No or primary education & 17 & 7 & 40 & 9 & $<0.01$ \\
\hline Technical or vocational training & 75 & 31 & 106 & 23 & \\
\hline Lower secondary education & 16 & 7 & 43 & 10 & \\
\hline Higher secondary education & 41 & 17 & 116 & 26 & \\
\hline Higher education & 97 & 39 & 149 & 33 & \\
\hline
\end{tabular}




\section{Anthropometric and metabolic characteristics}

About one third of the participating men were classified within the "normal" category for BMI, as well as for AC (Table 2). More men were classified in the highest risk category for AC. The shift to higher risk categories was even more prominent for women. Whereas about one in two women were in the lowest BMI risk category, there was a remarkable shift to the highest $\mathrm{AC}$ risk category.

Table 2

Proportions of participants per category of body mass index and abdominal circumference

\begin{tabular}{lcc}
\hline & $\begin{array}{c}\text { Men } \\
(\mathbf{n = 2 4 7 )}\end{array}$ & $\begin{array}{c}\text { Women } \\
(\mathbf{n = 4 5 8})\end{array}$ \\
\hline Body Mass index $\left(\mathrm{in} \mathrm{kg} / \mathrm{m}^{2}\right)$ & & \\
\hline Normal weight $(\mathrm{BMI}<25)$ & $31.6 \%$ & $46.7 \%$ \\
Overweight $(25<\mathrm{BMI}<30)$ & $45.7 \%$ & $34.9 \%$ \\
Obesity (BMI $\geq 30)$ & $22.7 \%$ & $18.3 \%$ \\
\hline Abdominal circumference (in cm) & & \\
\hline Normal risk $(\mathrm{M} \leq 94, \mathrm{~F} \leq 80)$ & $34.0 \%$ & $26.4 \%$ \\
Increased risk $(\mathrm{M} 94-102, \mathrm{~F} 80-88)$ & $28.7 \%$ & $23.6 \%$ \\
High risk $(\mathrm{M} \geq 102, \mathrm{~F} \geq 88)$ & $37.2 \%$ & $50.0 \%$ \\
\hline
\end{tabular}

$\mathrm{BMI}=$ body mass index, $\mathrm{AC}=$ abdominal circumference.

\section{Correlation between body mass index and abdominal circumference}

The Pearson's correlation coefficient ( $=\mathrm{rp})$ as well as the Spearman's rank-correlation coefficient $(=\mathrm{rs})$ showed a strong positive linear correlation between the BMI and the $\mathrm{AC}$ with $\mathrm{rp}$ and $\mathrm{rs}=0.87$

for the total study population (Figure 1). The Pearson's correlation coefficient showed also a strong positive linear correlation for men ( $\mathrm{rp}=$ $0.91)$ and women $(\mathrm{rp}=0.88)$, separately.

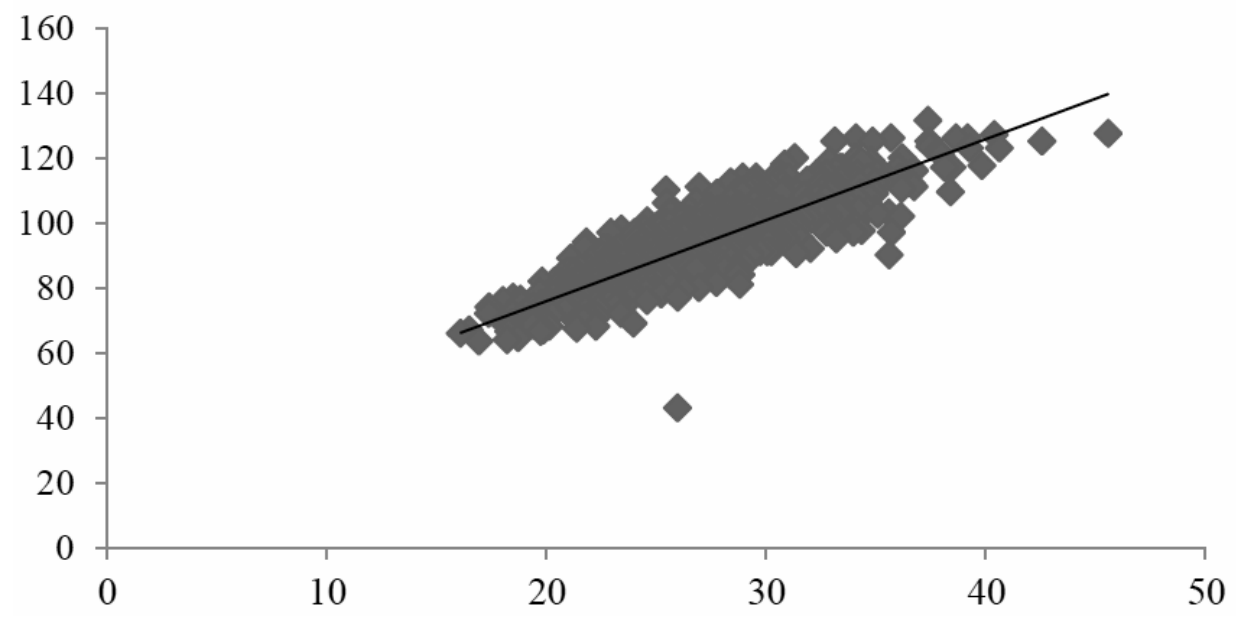

X-axes: Body mass index $\left(\mathrm{kg} / \mathrm{m}^{2}\right)$

Y-axes: Abdominal circumference $(\mathrm{cm})$

Figure 1. Scatterplot of the correlation between body mass index and abdominal circumference of the participants $\left(r_{p}=0.87 ; n=705 ; p<0.001\right.$ and $\left.r_{s}=0.87 ; n=705 ; p>0.001\right)$.

\section{Prevalence and relative risk for weight-related diseases}

In our study population, dyslipidemia was the most common weight-related disease for men as well as for women (Table 3). Hypertension was also an important weight-related disease. Joint problems were the only disease that occurred more among women than among men.

The use of the BMI to detect patients with a high risk for weight-related diseases was quite performant for about all diseases in women (Table 4). In men, the timely detection of patients with a higher risk for cardiovascular diseases was hampered. 
The AC was associated to most of the weight-related diseases, especially for hypertension (Table 5). However, the AC was not related with a higher relative risk for diabetes and gastroesophageal diseases in women and cardiovascular diseases and joint problems in men.

Table 3

Prevalence (in \%) of the most common weight-related diseases in men and women

\begin{tabular}{lccc} 
& $\begin{array}{c}\text { Men } \\
(\mathbf{n = 2 4 7})\end{array}$ & $\begin{array}{c}\text { Women } \\
(\mathbf{n = 4 5 8})\end{array}$ & p-value \\
\hline Hypertension & $27.5 \%$ & $25.3 \%$ & $\mathrm{NS}$ \\
Diabetes & $8.1 \%$ & $4.8 \%$ & $\mathrm{NS}$ \\
Cardiac diseases & $10.5 \%$ & $7.9 \%$ & $\mathrm{NS}$ \\
Vascular diseases & $1.6 \%$ & $2.8 \%$ & $\mathrm{NS}$ \\
Dyslipidemia & $33.6 \%$ & $30.1 \%$ & $\mathrm{NS}$ \\
Stroke & $1.6 \%$ & $1.5 \%$ & $\mathrm{NS}$ \\
Joint problems & $17.4 \%$ & $25.3 \%$ & $<0.05$ \\
Gastroesophageal disease & $4.9 \%$ & $5.2 \%$ & $\mathrm{NS}$ \\
Other diseases & $15.0 \%$ & $21.2 \%$ & $\mathrm{NS}$ \\
\hline
\end{tabular}

Table 4

Relative risk for various diseases according to the BMI categories for men and women

\begin{tabular}{|c|c|c|c|c|c|c|}
\hline & \multicolumn{3}{|c|}{ BMI men (in $\mathrm{kg} / \mathrm{m}^{2}$ ) } & \multicolumn{3}{|c|}{ BMI women (in $\mathrm{kg} / \mathrm{m}^{2}$ ) } \\
\hline & $<25.0$ & $25.0<30.0$ & $\geq 30.0$ & $<25.0$ & $25.0<30.0$ & $\geq 30.0$ \\
\hline & RR & RR & RR & RR & RR & \\
\hline & Ref & $(95 \% \mathrm{BI})$ & $(95 \% \mathrm{BI})$ & Ref & $(95 \% \mathrm{BI})$ & RR $(95 \% \mathrm{BI})$ \\
\hline \multirow{2}{*}{ Hypertension } & 1 & 1.7 & 3.1 & \multirow{2}{*}{1} & 1.7 & 3.0 \\
\hline & & $(0.9-3.1)$ & $(1.7-5.6)$ & & $(1.1-2.5)$ & $(2.1-4.4)$ \\
\hline \multirow{2}{*}{ Diabetes } & 1 & 1.4 & 5.1 & \multirow{2}{*}{1} & 1.2 & 3.3 \\
\hline & 1 & $(0.4-5.4)$ & $(1.5-18.0)$ & & $(0.4-3.4)$ & $(1.3-8.5)$ \\
\hline \multirow{2}{*}{ Cardiovascular diseases } & 1 & 1.9 & 1.4 & \multirow{2}{*}{1} & 1.5 & 2.1 \\
\hline & 1 & $(0.8-4.2)$ & $(0.5-3.7)$ & & $(0.8-2.7)$ & $(1.1-4.0)$ \\
\hline \multirow{2}{*}{ Dyslipidemia } & 1 & 1.9 & 2.4 & \multirow{2}{*}{1} & 1.3 & 1.6 \\
\hline & 1 & $(1.2-3.2)$ & $(1.4-4.1)$ & & $(0.9-1.8)$ & $(1.1-2.2)$ \\
\hline \multirow{2}{*}{ Joint problems } & 1 & 1.9 & 2.3 & \multirow{2}{*}{1} & 1.4 & 2.3 \\
\hline & & $(0.9-4.0)$ & $(1.0-5.1)$ & & $(1.0-2.1)$ & $(1.6-3.3)$ \\
\hline \multirow{2}{*}{$\begin{array}{l}\text { Gastro-oesophageal } \\
\text { diseases }\end{array}$} & 1 & 4.8 & 5.3 & \multirow{2}{*}{1} & 2.5 & 3.0 \\
\hline & 1 & $(0.6-38.5)$ & $(0.61-46)$ & & $(0.9-6.5)$ & $(1.0-8.6)$ \\
\hline \multirow[t]{2}{*}{ Other diseases } & 1 & 0.9 & 1.2 & \multirow[t]{2}{*}{1} & 1.3 & 1.0 \\
\hline & & $(0.4-1.7)$ & $(0.5-2.5)$ & & $(0.9-1.9)$ & $(0.6-1.7)$ \\
\hline
\end{tabular}

Table 5

Relative risk for various diseases according to abdominal circumference categories for men and women

\begin{tabular}{|c|c|c|c|c|c|c|}
\hline & \multicolumn{3}{|c|}{$\begin{array}{c}\text { Abdominal circumference } \\
\text { men (in cm) }\end{array}$} & \multicolumn{3}{|c|}{$\begin{array}{l}\text { Abdominal circumference } \\
\text { women (in cm) }\end{array}$} \\
\hline & $\begin{array}{l}\leq 94 \\
\text { RR } \\
\text { Ref }\end{array}$ & $\begin{array}{c}94-102 \\
\text { RR } \\
(95 \% \mathrm{BI})\end{array}$ & $\begin{array}{c}\geq 102 \\
\text { RR } \\
(95 \% \mathrm{BI})\end{array}$ & $\begin{array}{l}\leq 80 \\
\text { RR } \\
\text { Ref }\end{array}$ & $\begin{array}{c}80-88 \\
\text { RR } \\
(95 \% \mathrm{BI})\end{array}$ & $\begin{array}{c}\geq 88 \\
\text { RR } \\
(95 \% \mathrm{BI})\end{array}$ \\
\hline Hypertension & 1 & $\begin{array}{c}1.9 \\
(1.0-3.6)\end{array}$ & $\begin{array}{c}2.8 \\
(1.6-5.0)\end{array}$ & 1 & $\begin{array}{c}2.3 \\
(1.2-4.6)\end{array}$ & $\begin{array}{c}3.9 \\
(2.2-7.1)\end{array}$ \\
\hline Diabetes & 1 & $\begin{array}{c}0.6 \\
(0.1-3.1)\end{array}$ & $\begin{array}{c}3.2 \\
(1.1-9.3)\end{array}$ & 1 & $\begin{array}{c}0.6 \\
(0.1-3.0)\end{array}$ & $\begin{array}{c}2.1 \\
(0.7-6.2)\end{array}$ \\
\hline Cardiovascular diseases & 1 & $\begin{array}{c}0.8 \\
(0.3-2.1)\end{array}$ & $\begin{array}{c}1.5 \\
(0.7-3.0)\end{array}$ & 1 & $\begin{array}{c}1.6 \\
(0.6-4.0)\end{array}$ & $\begin{array}{c}2.7 \\
(1.2-5.9)\end{array}$ \\
\hline Dyslipidemia & 1 & $\begin{array}{c}1.4 \\
(0.9-2.5)\end{array}$ & $\begin{array}{c}3.2 \\
(1.7-6.2)\end{array}$ & 1 & $\begin{array}{c}1.2 \\
(0.8-2.0)\end{array}$ & $\begin{array}{c}1.8 \\
(1.2-2.7)\end{array}$ \\
\hline Joint problems & 1 & $\begin{array}{c}1.7 \\
(0.8-3.5)\end{array}$ & $\begin{array}{c}1.7 \\
(0.9-3.5)\end{array}$ & 1 & $\begin{array}{c}1.3 \\
(0.8-2.2)\end{array}$ & $\begin{array}{c}1.9 \\
(1.2-3.0)\end{array}$ \\
\hline Gastroesophageal diseases & 1 & $\begin{array}{c}1.8 \\
(0.3-10)\end{array}$ & $\begin{array}{c}3.2 \\
(0.7-15)\end{array}$ & 1 & $\begin{array}{c}1.5 \\
(0.3-6.5)\end{array}$ & $\begin{array}{c}3.0 \\
(0.9-10.0)\end{array}$ \\
\hline Other diseases & 1 & $\begin{array}{c}0.9 \\
(0.4-2.0) \\
\end{array}$ & $\begin{array}{c}1.1 \\
(0.6-2.3) \\
\end{array}$ & 1 & $\begin{array}{c}2.6 \\
(1.4-4.5) \\
\end{array}$ & $\begin{array}{c}2.0 \\
(1.2-3.6) \\
\end{array}$ \\
\hline
\end{tabular}




\section{DISCUSSION}

\section{Representativeness of our study population}

This study examined the anthropometric characteristics of a sample of the Belgian population. Some selection bias may have occurred by the fact that participants were recruited during a fair. Disabled persons or persons who are less mobile, or not at all interested in food were underrepresented in the sample. The fair was also preferably visited by people who are older than 40 years of age.

The proportion of obese men and women was higher in our study, as compared to the Belgian Health Interview Survey (HIS) of 2013 [2]. Our study population is not a representative sample of the adult population but rather of the population between 40 and 70 years of age.

\section{Identification of high-risk groups}

Forty-six percent of the men was overweight and $23 \%$ was obese. The prevalence among women was less: $35 \%$ for overweight and $18 \%$ for obesity.

Only $34 \%$ of men and $26 \%$ of women had a normal AC. The prevalence of increased AC with a high risk, was $50 \%$ in women, indicating that half of the female participants had a substantial increased risk of developing co-morbidities. In men, the prevalence rate in this category was $37 \%$.

Comparing the high-risk groups for BMI and $\mathrm{AC}$, it is remarkable that only $18 \%$ of the women are at high-risk according to the BMI, but $50 \%$ of women are at high-risk according to their AC. Among men, the difference was less striking but still significant: $23 \%$ of men are at high-risk according to the BMI, but $37 \%$ are at high-risk according to their AC.

A strong, significant and positive linear correlation was found between BMI and $\mathrm{AC}(\mathrm{r}=0.87)$. This correlation was strongly positive and significant for men $(r=0.91)$ and for women $(r=0.88)$. Thus, an increase in the BMI is associated with an increase in $\mathrm{AC}$, and vice versa, a decline in the $\mathrm{BMI}$ is correlated with a decrease in AC.

The observed correlation coefficients are similar to those from the meta-analysis by Vazquez et al. $(\mathrm{r}=0.88)$ for men and women together and the study by Flegal et al. where the correlation coefficient was 0.89 in men and 0.87 in women $[13,17]$.

\section{Relative risk for weight-related diseases}

The prevalence of weight-related diseases in our study is a good reflection of these diseases in a general obviously healthy population between 40 and 70 years of age, with a high prevalence for hypertension, dyslipidemia and joint problems.

With this kind of cross-sectional studies, it is only possible to search for relationships between risk factors and diseases. People with obesity or an increased AC had an increased relative risk of having hypertension, diabetes, cardiovascular disorders, dyslipidemia, joint problems or gastroesophageal diseases compared to persons with normal BMI or AC. In general, both women and men with obesity or a high risk increase of the $\mathrm{AC}$ have a greater relative risk than the peer group for the diseases studied.

Many review articles and meta-analyses had already observed that the measurement of the AC was not a better risk determinant of weight-related diseases including cardiovascular diseases, hypertension and diabetes, as compared to the BMI [10$12,14,15]$. In our study, the relative risks for various diseases for people with highly increased $\mathrm{AC}$ or BMI are quite similar. However, it should be mentioned that cardiovascular diseases were not identified with a higher relative risk in men with obesity. Neither had diabetes a higher relative risk in women with a high risk increased AC.

These results do not permit to make a choice between the BMI or the AC to identify people with a higher risk for weight-related disorders. We are aware that this might be related to our study population, which is mainly aged between 40 and 70 years. In a younger population, where the body weight is more related to the muscle mass, the AC may still be a better identifier for people with a higher risk for weight-related disorders. Thereupon, we need to be aware of the risk to use AC in people at middle and old age because more people (especially women) are identified in the high-risk group and perhaps diagnosed incorrectly.

It remains intriguing how almost 3 times as many women belong to the high-risk group when we use $\mathrm{AC}$ instead of BMI, and this despite the high correlation between BMI and AC. This suggests that the cutoffs for $\mathrm{AC}$ or BMI (of both) are wrongly selected. The distribution of BMI and AC in our study does not suggest that perhaps there are more participants with AC near the cutoff for BMI.

From these observations, it is not surprising that we experience significant problems for those diseases which occur less frequently in this population. 


\section{Novelty and added values}

This is one of the first studies that examine the correlation between BMI and $\mathrm{AC}$ and their association with weight-related diseases in an adult Western-European population. It clarifies whether it is better to use the BMI or AC to estimate the risk for these diseases.

\section{Limitations of the research}

Most of the participants were aged between 40 and 70 years, what has consequences on the representativeness of our sample population. However, after comparison with the Belgian HIS, we can conclude that our study population is representative for the Belgian population aged between 40 and 70 years [2].

But the study had also several other limitations. The questionnaire used was not standardized. All measurements were carried out during the day while most of the participants had eaten or drunk something what could influence the gastro-intestinal content, with a possible impact on the accuracy of the measurements of the AC [6]. Finally, the ethnicity was never questioned by the researchers.

\section{CONCLUSION}

There is a strong positive correlation between the BMI and the AC. In the identification of patients at high-risk for weight-related diseases, the use of the AC identifies more patients than the BMI. Especially more women are ranking in a higher-risk class with the $\mathrm{AC}$ than with the $\mathrm{BMI}$ classification. Both the BMI as well as the $\mathrm{AC}$ identify most patients with an increased relative risk, however cardiovascular diseases are not identified in men with the BMI, and diabetes is not identified in women with the AC. There are too few arguments to prefer the use of $\mathrm{AC}$ above the BMI to detect people at high-risk for weight-related diseases.

Acknowledgements. The authors would also like to thank David Proot for the English language editing and the Brussels Food Fair and National Science Day for giving the opportunity to collect our data at their fair.

Declaration of interests. The authors have no financial or personal relationships with other people or organizations that could inappropriately influence their work. There are no conflicts of interest.

Role of the funding source. The study was not funded.

Introducere. Indicele de masă corporală (BMI) este folosit pentru a evalua riscul asociat obezității. Totuşi şi circumferința abdominală (CA) poate fi folosită pentru estimarea acestui risc. Scopul studiului este de a evalua asocierea dintre $B M I$ şi $C A$.

Materiale şi Metode. Pacienții au fost recrutați dintre participanții unui târg gastronomic din Bruxelles în anul 2014. Aceştia au completat un chestionar privind antecedentele personale patologice şi li s-au evaluat tensiunea arterială, greutatea, inălțimea şi $C A$.

Rezultate. Au fost recrutați 705 participanți. Bărbații au avut în medie un BMI de $27.3 \mathrm{~kg} / \mathrm{m}^{2}$ şi o CA în medie de $98.7 \mathrm{~cm}$. Femeile au avut în medie un BMI de $26.0 \mathrm{~kg} / \mathrm{m}^{2}$ şi o CA în medie de $88.2 \mathrm{~cm}$. Coeficientul Pearson de corelatie între BMI şi CA a fost de 0.91 pentru bărbați şi 0.88 pentru femei, fiind astfel o corelație puternică între aceste două variabile. Folosind $C A$, aceasta a identificat mai mulți pacienți aflați la risc decât BMI (mai ales pentru genul feminin). Atât BMI cât şi $C A$ au identificat majoritatea patologiilor cu un risc relativ crescut.

Concluzii. Este o corelație strânsă între BMI şi CA, însă există prea puține argumente care să indice mai degrabă utilizarea CA față de BMI pentru a identifica persoanele la risc pentru comorbidități asociate obezității.

Correspondence to: Dirk DEVROEY, Vrije Universiteit Brussel (VUB),

Head of the Dept of Family Medicine and Chronic Care, Laarbeeklaan 103, B-1090, Brussels, Belgium

Tel: +32 2 477.43.11, Fax: +32 2477.43 .01

E-mail: dirk.devroey@vub.ac.be 


\section{REFERENCES}

1. World Health Organization. Obesity: preventing and managing the global epidemic- report of a WHO Consultation on obesity. 2000, Geneva: WHO. Available at http://www.who.int/nutrition/publications/obesity/WHO_TRS_894/en/ (date of accession: 16 July 2016).

2. DRIESKENS S. Voedingsstatus. In: Gezondheidsenquet̂te 2013. Rapport 2: Gezondheidsgedrag en leefstijl. WIV-ISP, Brussel, 2014 Available at https://his.wiv-isp.be/nl/Gedeelde\%20\%20documenten/summ_LS_NL_2013.pdf (date of accession: 16 July 2016).

3. SIMMONDS M., BURCH J., LLEWELLYN A., GRIFFITHS C., YANG H., OWEN C., et al. The use of measures of obesity in childhood for predicting obesity and the development of obesity-related diseases in adulthood: a systematic review and metaanalysis. Health Technol Assess. 2015; 19(43):1-336.

4. OLIVEROS E., SOMERSVK., SOCHOR O., GOEL K., LOPEZ-JIMINEZ F. The concept of normal weight obesity. Prog Cardiovasc Dis. 2014; 56(4):426-33.

5. LEAN ME., HANTS., MORRISON CE. Waist circumference as a measure for indicating need for weight management. BMJ. $1995 ;$ 311(6998):158-61.

6. World Health Organization. Waist Circumference and Waist-Hip Ratio: Report of a WHO Expert Consultation. 2008, Geneva: WHO. Available at http://apps.who.int/iris/bitstream/10665/44583/1/9789241501491_eng.pdf (date of accession: 16 July 2016).

7. STEVENS J., KATZ EG., HUXLEY RR. Associations between gender, age and waist circumference. Eur J ClinNutr. 2010; 64(1):6-15.

8. LEAR SA., JAMES PT., KO GT., KUMANYIKA S. Appropriateness of waist circumference and waist-to-hip ratio cutoffs for different ethnic groups. Eur J ClinNutr. 2010; 64(1):42-61.

9. LASSEK WD., GAULIN SJ. Changes in body fat distribution in relation to parity in American women: a covert form of maternal depletion. Am J Phys Anthropol. 2006; 131(2):295-302.

10. HUXLEY R., JAMESWP., BARZI F, PATEL JV., LEAR SA, SURIYAWONGPAISAL P., et al. Obesity in Asia Collaboration. Ethnic comparisons of the cross-sectional relationships between measures of body size with diabetes and hypertension. Obes Rev. 2008; 9(S1):53-61.

11. LEE CM., HUXLEY RR., WILDMAN RP., WOODWARD M. Indices of abdominal obesity are better discriminators of cardiovascular risk factors than BMI: a meta-analysis. J Clin Epidemiol. 2008; 61(7):646-53.

12. HUXLEY R., MENDIS S., ZHELEZNYAKOV E., REDDY S., CHAN J. Body mass index, waist circumference and waist-hip ratio as predictors of cardiovascular risk: a review of the literature. Eur J Clin Nutr. 2010; 64(1):16-22.

13. VAZQUEZ G., DUVAL S., JACOBS DRJr., SILVENTOINEN K. Comparison of body mass index, waist circumference, and waist/hip ratio in predicting incident diabetes: a meta-analysis. Epidemiol Rev. 2007; 29:115-28.

14. QIAO Q., NYAMDORJ R. The optimal cutoff values and their performance of waist circumference and waist-to-hip ratio for diagnosing type II diabetes. Eur J Clin Nutr. 2010; 64(1):23-9.

15. SEIDELL JC. Waist circumference and waist/hip ratio in relation to all-cause mortality, cancer and sleep apnea. Eur J Clin Nutr. 2010; 64(1):35-41.

16. CERHAN JR., MOORE SC., JACOBS EJ., KITAHARACM., ROSENBERG PS., ADAMI HO., et al. A pooled analysis of waist circumference and mortality in 650,000 adults. Mayo Clin Proc. 2014; 89(3):335-45.

17. FLEGAL KM., GRAUBARD BI. Estimates of excess deaths associated with body mass index and other anthropometric variables. Am J Clin Nutr. 2009; 89(4):1213-9.

Received July 27, 2016 